Vol. 2, No. 1, 2021

\author{
Maksym Kaleniuk ${ }^{1}$, Oleg Furman ${ }^{2}$, Taras Postranskyy ${ }^{2}$ \\ 1. Millhouse Logistics Inc \\ 6, Akademika Pidstryhacha Str., Lviv, 79000, Ukraine \\ 2. Lviv Polytechnic National University \\ 12, Bandery Str., Lviv, 79000, Ukraine \\ (C) Kaleniuk M., Furman O., Postranskyy T., 2021 \\ https://doi.org/ 10.23939/tt2021.01.039
}

\title{
INFLUENCE OF TRAFFIC FLOW INTENSITY ON ENVIRONMENTAL NOISE POLLUTION
}

\begin{abstract}
Summary. The modern urban environment, with the development of industry, the growth of the vehicle's number on the roads, and the increase in the density of buildings, is increasingly capable of negatively affect the health and well-being of the city's population. Among the factors influencing the environment is noise pollution, namely man-made noise - unwanted and harmful sounds created as a result of human activities. Today, noise is one of the most common factors of pollution among all others. The most common source of noise pollution is transport, including cars and trucks, buses, railways, airplanes, etc. The negative phenomenon of traffic noise is that almost everyone is greatly affected. This can often be accompanied by other harmful factors, such as vibration. According to scientific researches, noise can cause irritation under constant acoustic exposure. As a result, there are sleep disorders, decreased mental capacity, and the development of stress, and stress development in humans. Traffic noise is created from the operation of engines, the friction of wheels with the road surface, brakes, and aerodynamic features of vehicles, etc. In general, the level of traffic noise depends on such basic indicators as the intensity, speed, and composition of the traffic flow. Therefore, an important task is the study of traffic noise, its measurement, the establishment of appropriate dependencies, and further evaluation of the results. Knowing the level of noise generated by vehicles, further measures to reduce it are possible, such as redistribution of traffic flows on the road network, speed limits, improving the quality of the road surface, the use of basic means of reducing noise pollution, the use of noise protection devices, etc. Based on this, the negative impact of this phenomenon on the human body and the environment, in general, can be reduced.
\end{abstract}

Key words: traffic flow, noise pollution, traffic flow intensity, noise meter, road surface, traffic flow composition.

\section{INTRODUCTION}

Nowadays, noise has become an integral part of life. It is found almost everywhere and, unfortunately, has a large, mostly negative, impact on people and the environment. The term "noise" means the sound that goes beyond sound comfort. Noise has a different frequency, strength, height, and duration. It is often an unwanted sound that has a negative effect on human performance, interferes with the perception of information, and affects the quality of recreation. From the physical point of view, the phenomenon of noise is created thanks to compression and rarefaction of air masses, namely there are fluctuating changes of air pressure $[1,2]$. It should be noted that the noise can be: permanent, nonpermanent, intermittent, impulse, etc. 
Considering the impact of noise on the environment, the concepts of sensitivity threshold and pain threshold are mentioned. The sensitivity threshold is characterized by minimum sound intensity. The opposite is the pain threshold with the maximum sound intensity at which the hearing organs feel pain.

Traffic noise is a clear feature of the urban environment. It can occur due to incorrect urban planning, where the sources with high noise (airports, highways, industrial enterprises, etc) are located within them. Each year, the impact of noise from transport sources on the environment is constantly growing. Due to the increase in the number of vehicles and increasing of the city economy technical equipment that leads to interaction between the city and the natural environment.

Sound is a natural phenomenon that affects all living organisms. In nature, loud sounds are a rare thing, and the usual noise is short and relatively weak. The sound intensity means a change in sound pressure in the air. The volume depends on the frequency of the sound. The human ear perceives a frequency range that is between 16 and $20 \mathrm{~Hz}$. The sound that is lower than these values is called infrasound, and higher - ultrasound [3].

Noise is a phenomenon that negatively affects the body's systems, sleep, attention, etc. It is often a factor that increases irritability, anxiety, and leads to depression. Constant and significant noise levels affect a person's hearing, which can lead to deterioration or even loss of it. Unwanted sounds weaken and distract, impair the ability to receive and reproduce information normally, reduce work activity and normal rest, affect a person's mental health, etc $[4,5]$.

\section{RESEARCH STATEMENT}

The purpose of the article is to identify the pattern of changes in the noise level from the intensity of traffic. To achieve this, the following tasks are accomplished:

- to analyze the parameters of the road network sections on which the research will be conducted;

- to analyze noise research methods and select the appropriate equipment;

- to research the road traffic intensities and the noise level it creates;

- to analyze the obtained data and to establish the dynamics of changes in the noise level from the road traffic flow intensity.

\section{TRAFFIC FLOW AND ITS IMPACT ON THE LEVEL OF NOISE POLLUTION}

Transport development and technical progress of cities are the main sources of noise pollution and factors that change the natural noise level. As a result, new oscillation frequencies are not typical for the environment. As for traffic noise, which can be generated on sections of roads and streets, it depends on various factors (Fig. 1) [1, 4, 6].

The most common source of traffic noise is a vehicle, in particular a car. In this case, the noise is created by car units, namely the engine, body, accessories, tires, etc. Nowadays, there are many solutions how to reduce the level of car noise, for example, by improving the acoustic characteristics and technical solutions in the design and manufacture of vehicles. Also, the noise level can be reduced by creating protection at the place of its appearance. It should be noted, the transport factors that affect the noise level include $[1,4,6,7]$ :

- traffic intensity;

- speed of the traffic flow;

- traffic flow composition;

- the operational condition of the vehicle;

- cargo parameters, etc.

As for road network factors influencing the noise level, it can be $[1,4,6,7]$ :

- traffic density;

- profiles of the road or street;

- the presence of intersections and their parameters;

- type of road surface; 
- the number of lanes and the presence of road dividing lanes;

- availability of public transport stops.

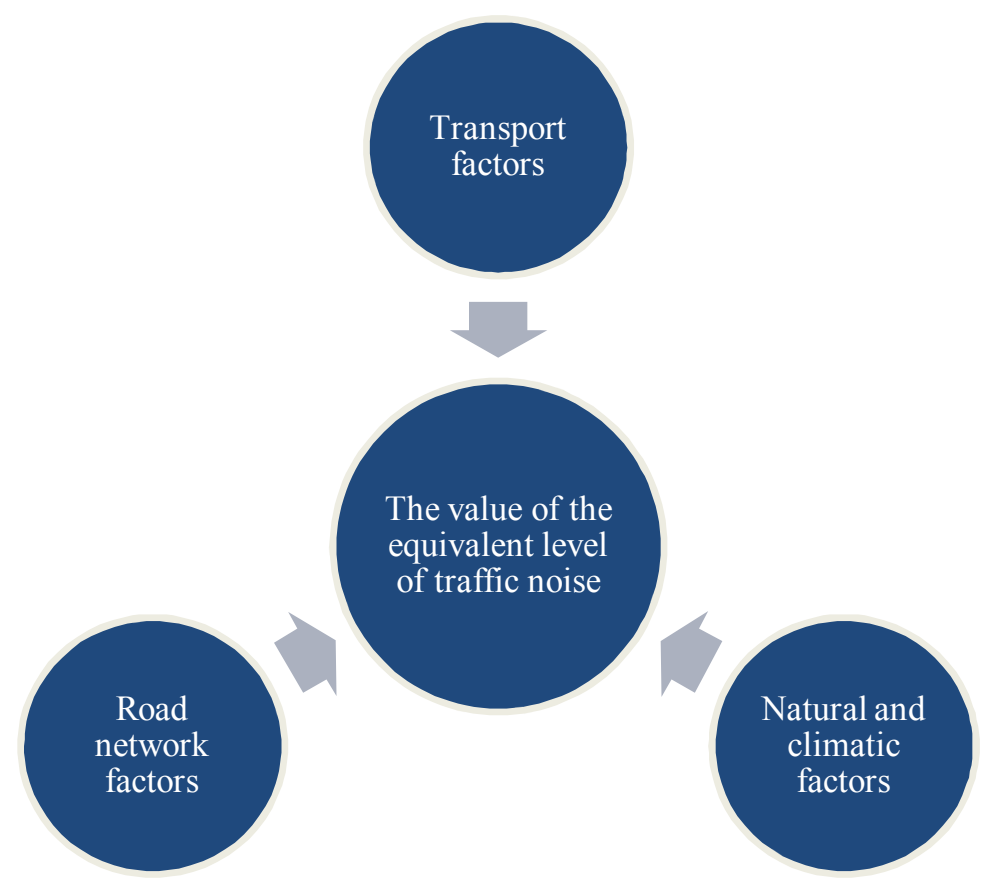

Fig. 1. Factors that influence the level of traffic noise [1, 4, 6]

Natural and climatic factors influencing the noise level are divided into the following $[1,4,6,7]$ :

- atmospheric pressure;

- air temperature;

- wind speed and its other parameters;

- rainfall, etc.

The author of the scientific work [8] remarks that the noise level depends on the intensity of traffic and the speed of vehicles in it. According to the dependencies in this work, it can be concluded that the noise level reaches maximum values with a significant intensity of traffic flow and high speed of cars. In this case, the movement of vehicles in dense traffic has significant differences from the movement of a single car in the free movement conditions. The noise level is also affected by changes in traffic conditions, which is associated with different modes of the car engine's operation.

In the scientific paper [9], the authors found that with increasing speed, the noise level also increases. These took into account the noise from the engine and tires of the car. So speed has a significant effect on noise. At low speeds, the noise level is small, but the frequency and intensity of acceleration can significantly affect the noise level. The effect of increasing acceleration noise is usually inconspicuous at speeds more than $50 \mathrm{~km} / \mathrm{h}$. Also, there is reflected that the noise from the wheels begins to occur at speeds greater than $20 \mathrm{~km} / \mathrm{h}$ and is constantly increasing.

It should be noted that the noise reduction depends on the distance to its source. It is clear that at a great distance from the noise source, its value is insignificant and close to zero. However, according to the results given in [10], the noise reduction also depends on the type of road surface on which the car moves. For example, the vehicle driving on an asphalt road has the best dynamics of noise reduction, the ground the worst indicators, and the lawn - the lowest dynamics. Therefore, the noise, in this case, largely depends on the friction of tires with a certain type of road surface.

A not less important factor influencing the level of noise pollution is the composition of the traffic flow. It is known that the greater rate of freight transport in the total number of vehicles leads to the greater noise level. At the same time, the operational condition of these vehicles and the cargo they transport have a rather important role [11-13]. 
Following the above, it can be argued that there is a great impact of vehicles and their flows on the noise level they create.

Given the trends in increasing the number of vehicles in settlements, the importance of studying its impact on noise pollution is growing. This type of research can be carried out using different methods, techniques, and approaches. One of the most common methods is research on the roads. These methods make it possible to obtain reliable traffic information and reflect the exact characteristics of traffic flows. The main ways of noise study are its measurement using special instruments and equipment. High accuracy of the results can be obtained with the help of special highly sensitive devices - noise meters. In Ukraine, the requirements for these devices are set according to state standards (DSTU 2867-94) [14]. Noise meters are used to measure noise levels for sanitary control at workplaces, on residential and public buildings, and in different territories.

Noise pollution can also be assessed using different software. As an example, it can be taken the software "APM Acoustics 3D" (APM Akustyka 3D) [15]. It is created to automate the activities of assessing the acoustic impact of noise sources on the objects of a particular area, buildings, etc. This program can be used in carrying out projecting the location of new facilities, assessing the impact of objects` noise on the environment, calculating the noise characteristics of traffic flows, also to assess the effectiveness of projects to reduce external noise, etc.

Noise measurements are also can be made with mobile device applications. The accuracy of measurements depends on the physical properties of sensors and the accuracy of the received signal's software processing, as well as its output for further processing. Depending on the model of the mobile phone and the characteristics of the microphones, which affect the quality of measurements, results are significantly different. Therefore, such devices are rarely used for large-scale research. However, these applications are often free, making them accessible to anyone. Once installed, they allow you to measure the noise level using the technical capabilities of the phone. The disadvantage of these programs is a significant dependence on the quality of the smartphone, which affects the receipt of accurate measurement results.

Each task contains the initial data and the purpose which is reached in the process of its solution. In the case of noise pollution, the most commonly used inputs are the intensity and composition of the traffic flow. According to the data presented in the article [16], the expected level of traffic noise $\left(L_{A}\right)$ can be calculated by the following formula:

$$
L_{A_{\text {eq } 7.5}}=L_{\text {Atrp } 7.5}+\Delta L_{\text {Avant }}+\Delta L_{\text {Ashv }}+\Delta L_{A y}+\Delta L_{\text {Apokr }}+\Delta L_{\text {Arc }}+\Delta L_{\text {Aper }}
$$

where $L_{A t r p 7 \text { r } 5}$ - the calculated value of the equivalent sound level of the traffic flow with traffic intensity in both directions, fixed at a distance of $7.5 \mathrm{~m}$ from the axis of the near lane and a height of $1.5 \mathrm{~m}$ above the level of the carriageway; $\Delta L_{\text {Avant }}$ - a correction that takes into account trucks and buses in the traffic flow; $\Delta L_{A s h v}$ - a correction that takes into account the average speed; $\Delta L_{A y}$ - a correction that takes into account the value of the longitudinal slope; $\Delta L_{A p o k r}$ - a correction that takes into account the type of road surface; $\Delta L_{A r c}$ - a correction that takes into account the width of the central dividing lane; $\Delta L_{\text {Aper }}$ - a correction that takes into account the presence of road crossings.

Approximately the noise from the traffic flow depending on the intensity of vehicles movement with high intensities (1000-5000 vehicles/hour) can be determined by the formula [8]:

$$
L_{A}=72+10 \lg \frac{N}{1000},
$$

where $N$ - traffic flow intensity, vehicles/hour.

In the DSTU-N B. V.1.1-33: 2013, it is proposed to determine the noise level by the formula [17]:

$$
L_{A_{\mathrm{eq}}}=44+0.26 V+10 \lg \left(N_{z} / V_{z}\right)+\Delta L_{A p o k r}+\Delta L_{A y} \text {, }
$$

where $V$ - average speed on the part of the street, $\mathrm{km} / \mathrm{h} ; N_{z}$ - calculated traffic intensity by formula (4), p.c.u.; $V_{z}$ - calculated traffic speed by formula (5), $\mathrm{km} / \mathrm{h}$.

$$
N_{z}=N_{l}+4 N_{b l}+4 N_{b c}+4 N_{b b},
$$




$$
V_{z}=V_{l}+1.14 V_{b l}+1.18 V_{b c}+1.22 V_{b b},
$$

where $N_{l}, V_{l}$ - respectively, the intensity and speed of cars and their modifications and trucks with a maximum permissible weight up to $3.5 \mathrm{t}$.; $N_{b l}, V_{b l}$ - respectively, the intensity and speed of trucks and buses with a maximum permissible weight up to $5 \mathrm{t}$. inclusive; $N_{b c}, V_{b c}$ - respectively, the intensity and speed of trucks and buses with a maximum permissible weight from 5t. to 12t. inclusive and trolleybuses; $N_{b b}, V_{b b}$ - respectively, the intensity and speed of trucks and buses with a maximum permissible weight of more than $12 \mathrm{t}$.

Autor, in paper [8], proposed to determine the numerical calculation of noise level by such the formula:

$$
L_{A e q}=10 \log \left(\int_{z_{1}}^{z_{2}} 10^{0,1 L} d z\right)+10 \cdot \log (\rho(z)),
$$

where $\rho$ - traffic density; $z$ - a fragment of the road between point $z_{1}$ and $z_{2}$.

Therefore, noise is a great pollutant of the environment and is a problem of the modern state of urbanization. Noise reduction measures in any modern city are an integral part of the activities to ensure comfortable and safe living conditions for its inhabitants.

\section{CONDUCTING RESEARCH AND ANALYSIS OF THE OBTAINED RESULTS}

The level of noise depends on such basic indicators of traffic flow as the intensity, composition, speed of cars, etc. One of the main tasks in this article is to study the intensity of traffic, the values of noise pollution, and to establish dependence between them. The needed indicators on the road network were studied, as it can give obtain high accuracy and reliability of results. To facilitate the analysis of traffic flow, the equipment for video recording was used. With the help of video records under certain conditions, high accuracy of registration of traffic flow parameters is provided, as well as long-term saving and reusability for analysis and demonstration. A noise meter model Flus ET-965 was used to measure the noise level (Fig. 2) [18].

It was decided that the measuring device should be located at a distance of $(7.5 \pm 0.2) \mathrm{m}$ from the point of measurement (the lane or direction of cars' movement) and a height of $(1.5 \pm 0.1) \mathrm{m}$ from the level of the roadway.

Among the conditions of measurements, the following were taken into account:

- places for research were selected on straight sections of streets and roads;

- measurements were carried out on sections of streets and roads with a clean and dry surface of the carriageway;

- measurements were not performed during precipitation, fog, and wind speeds of more than $5 \mathrm{~m} / \mathrm{s}$;

- during research, the measuring equipment mustn't be exposed to vibration and electric or magnetic waves;

- during research, the main axis of the measuring microphone should be directed towards the traffic flow and perpendicular to the direction of the road;

- the researcher must be at a distance of at least $0.5 \mathrm{~m}$ from the measuring microphone to prevent unwanted sound reflections;

- it was not allowed for people and foreign objects to be between the measuring microphone and the traffic flow.

To determine the level of noise pollution and to register the main characteristics of traffic flows, several sections of the Lviv road network were selected. In addition to flow indicators, the type

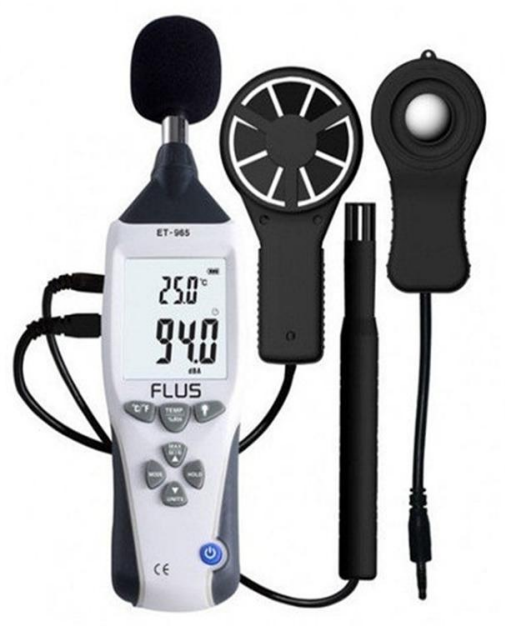

Fig. 2. Noise meter Flus ET-965 [18] 
of road surface was taken into account as one of the factors influencing the noise level. The research was conducted on the following typical street sections of the city:

1. Street with two lanes in both directions and with the asphalt road pavement (Fig. 3a);

2. Street with two lanes in both directions with the road pavement - cobblestones (Fig. 3b);

3. Street with three lanes in both directions, with a dividing lane, and with the asphalt road pavement (Fig. 3c).
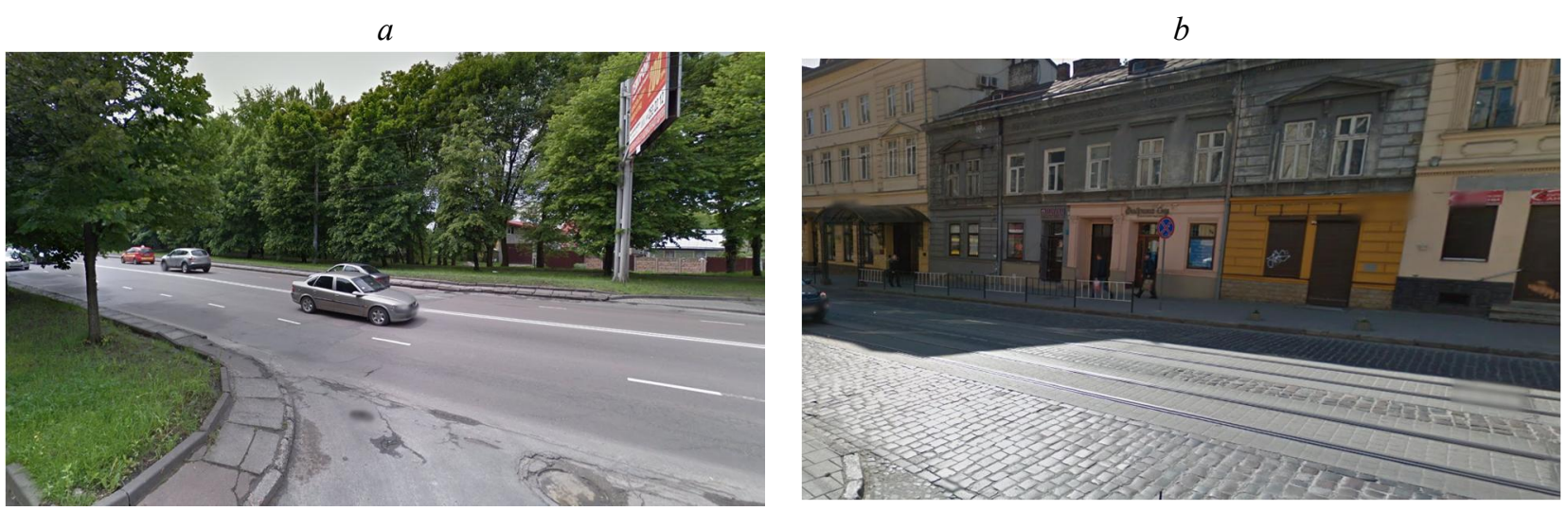

$c$

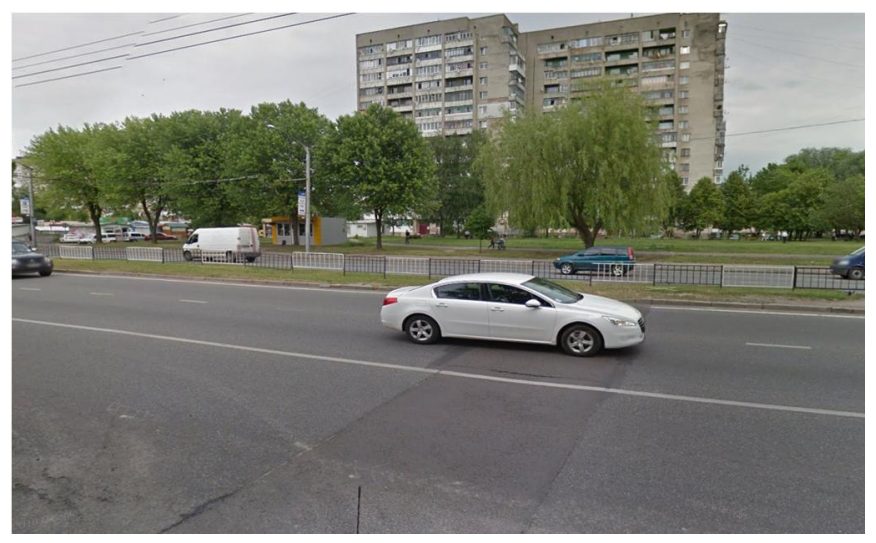

Fig. 3. Typical street sections of the city where the research was conducted:

$a-$ street with two lanes in both directions and with the asphalt road pavement;

$b$-street with two lanes in both directions with the road pavement - cobblestones;

$c$-street with three lanes in both directions, with a dividing lane, and with the asphalt road pavement

The peculiarity of the first type of the road network section was that there are a significant number of bus and trolleybus routes. The second typical section was located on the main street of the city and there is a movement of trams, the tracks of which pass through the central part. At the same time on this typical street section, the road surface is at a fairly close distance to houses. The third typical section is also located on one of the main streets. In this case, investigations were performed in a place with an asphalt surface and the presence of a dividing lane. At the same time, houses and residential areas are located at a sufficient distance from the roadway. The above-mentioned places of research were chosen, taking into account their planning parameters.

During the recording of the vehicles` movement, special forms were used. During fifteen minutes, the number of vehicles that crossed the section of the street was counted. Also, they were classified by types according to their parameters. During the above-mentioned research, video recording was also used. This allowed to reduce the duration of traffic researching on the road network and to continue the counting of vehicles in laboratory conditions. 
The traffic intensity of vehicles moving in the studied street sections was measured at 15-minute intervals for each hour of peak and inter-peak periods. Based on the established data, the average hourly value of this indicator is determined. The noise was measured during the video recording of traffic movement using the noise meter Flus ET-965. The device automatically and continuously displayed the noise value throughout the whole study period.

The obtained data of the research results were processed in laboratory conditions. The value of traffic intensity in personal car units (p.c.u) was calculated using the following formula [19]:

$$
N_{p}=\sum N_{F_{-} i} \cdot K_{p_{-} i},
$$

where $N_{F_{-} i}$ - factual traffic intensity in units of different types of vehicles, vehicle $/ \mathrm{h} ; K_{3 \beta_{-} i}-$ the coefficient that transforms the intensity in a particular vehicle`s types into intensity in personal car units (The values of these coefficients are selected according to DBN B. 2.3-4: 2015) [20].

The results of the study of the traffic flow intensity and the value of the noise they generate were shown in tabular forms. A fragment of such data is given in Table 1.

Table 1

\section{A fragment of the results of traffic flow intensity research and the value of the noise generated by it}

\begin{tabular}{|c|c|c|c|c|c|c|}
\hline \multirow[b]{2}{*}{$\begin{array}{l}\text { Research } \\
\text { period }\end{array}$} & \multicolumn{2}{|c|}{ Typical street sections No. 1} & \multicolumn{2}{|c|}{ Typical street sections No. 2} & \multicolumn{2}{|c|}{ Typical street sections No. 3} \\
\hline & $\begin{array}{l}\text { The average value } \\
\text { of traffic intensity } \\
\text { in personal car } \\
\text { units, p.c.u./h. }\end{array}$ & $\begin{array}{c}\text { Average } \\
\text { data of } \\
\text { noise, } \\
\text { dBA }\end{array}$ & $\begin{array}{l}\text { The average value } \\
\text { of traffic intensity } \\
\text { in personal car } \\
\text { units, p.c.u./h. }\end{array}$ & $\begin{array}{l}\text { Average } \\
\text { data of } \\
\text { noise, } \\
\text { dBA }\end{array}$ & $\begin{array}{l}\text { The average } \\
\text { value of traffic } \\
\text { intensity in } \\
\text { personal car } \\
\text { units, p.c.u./h. }\end{array}$ & $\begin{array}{c}\text { Average } \\
\text { data of } \\
\text { noise, } \\
\text { dBA }\end{array}$ \\
\hline 08:00-09:00 & 636 & 58 & 812 & 70 & 1622 & 65 \\
\hline 09:00-10:00 & 564 & 51 & 754 & 68 & 1546 & 62 \\
\hline $10: 00-11: 00$ & 531 & 51 & 723 & 65 & 1534 & 61 \\
\hline $11: 00-12: 00$ & 543 & 53 & 746 & 67 & 1525 & 60 \\
\hline $12: 00-13: 00$ & 585 & 55 & 734 & 67 & 1575 & 64 \\
\hline $13: 00-14: 00$ & 594 & 56 & 749 & 68 & 1551 & 63 \\
\hline
\end{tabular}

Based on the initial data, exactly the intensity of traffic flows and the corresponding values of noise pollution, dependencies for each of the researched typical street section were created (Fig. 4 - Fig. 6).

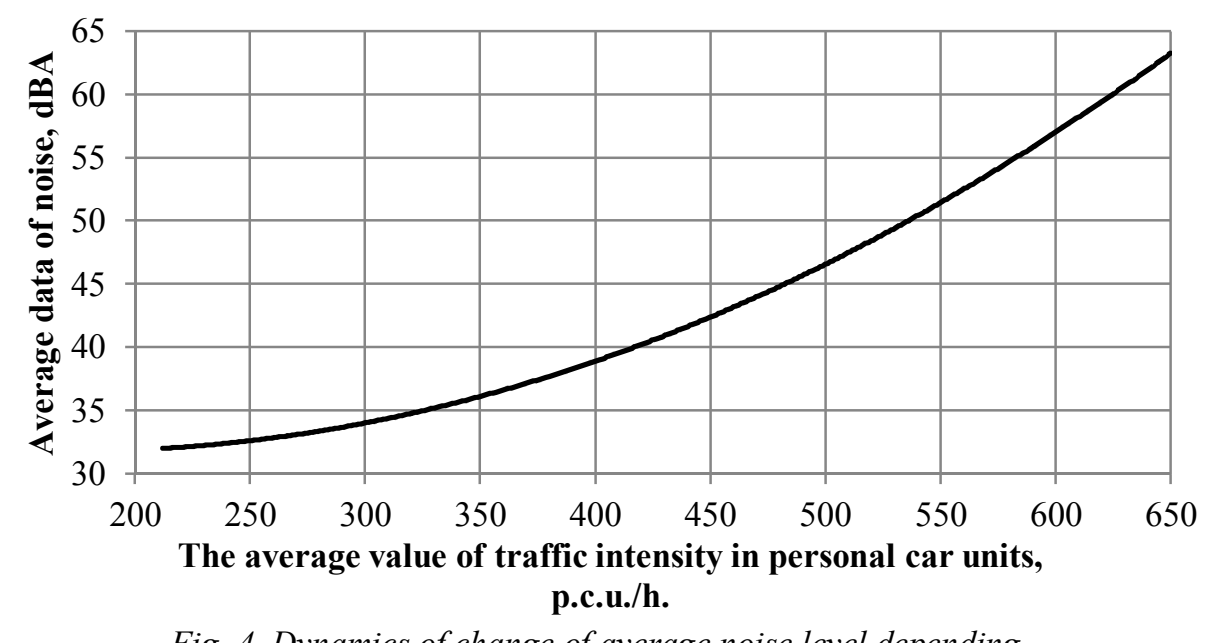

Fig. 4. Dynamics of change of average noise level depending on the average value of traffic intensity (p.c.u.) on typical street sections No. 1 


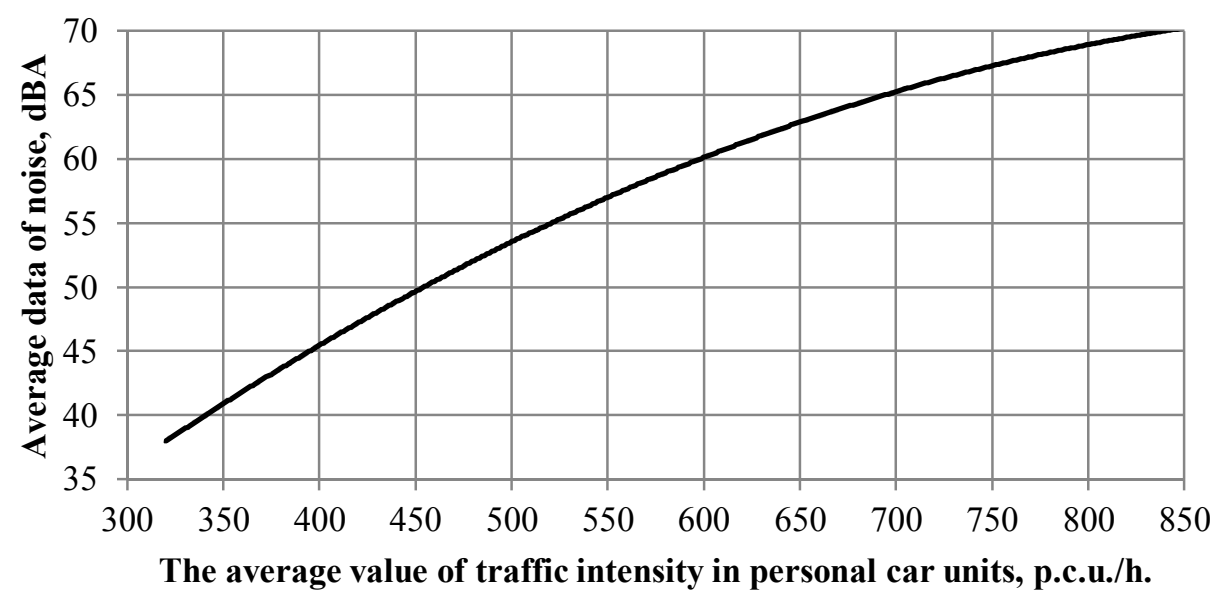

Fig. 5. Dynamics of change of average noise level depending on the average value of traffic intensity (p.c.u.) on typical street sections No. 2

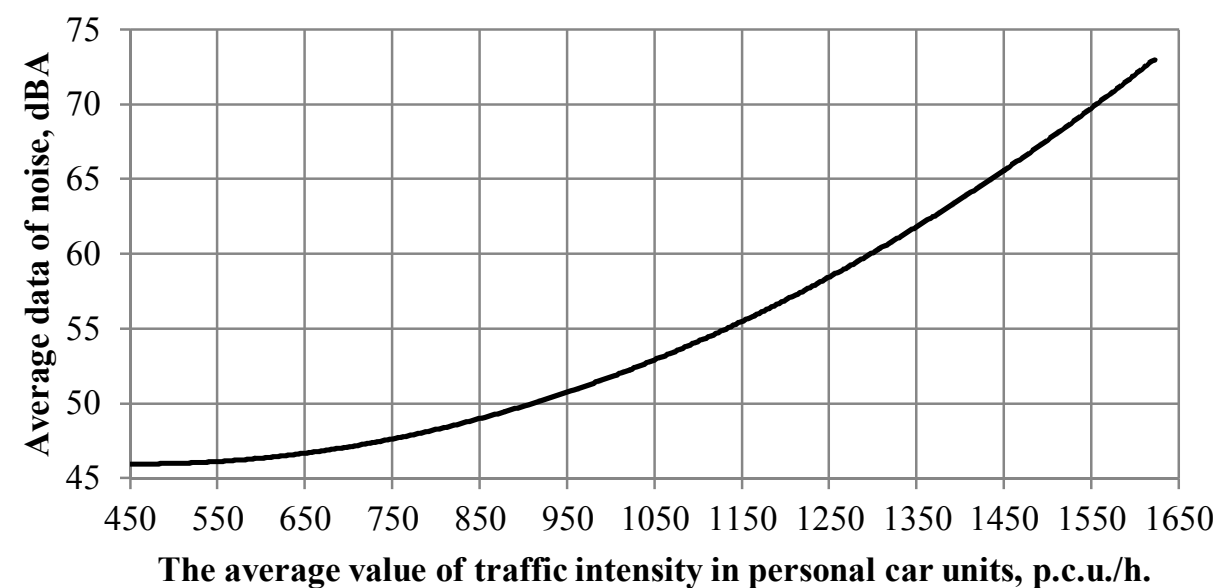

Fig. 6. Dynamics of change of average noise level depending on the average value of traffic intensity (p.c.u.) on typical street sections No. 3

During the research, it was established that the highest value of traffic intensity was observed in the period from 8:00 to 9:00. At the same time, the value of the noise level directly depended on the number of cars moving on the street. A significant part of the traffic flow was cars (personal), which create a lower level of noise pollution than trucks and buses. Comparing the above-shown dependencies, it was found that the average value of the generated noise, taking into account the intensity of traffic, is greater in typical sections No. 2. This is because there are cobblestones on the road surface. There was also a significant number of public transport in this researched area, and in particular, the presence of trams, which is perhaps the largest source of noise in this street and has a great impact on the level of noise pollution.

According to DBN V.1.1-31:2013, the maximum level of noise near the buildings can be $65 \mathrm{dBA}$ [21]. As is shown in Fig. 5 and Fig. 6, the generated noise level exceeds the permissible norms. At the same time, on the typical section No. 2, these values begin to exceed the permissible level at a traffic intensity of more than 690 p.c.u/h, and on the typical section No. 3 - at 1410 p.c.u/h.

\section{CONCLUSIONS AND RESEARCH PERSPECTIVES}

1. The influence of traffic intensity on the generated noise level created by it is researched. The measurements took into account the conditions of the research, in particular, the absence of additional factors influencing the equipment used. Also, one of the main stages of preparation for the research was the 
analysis of the existing methods of collecting data on the traffic flows and theoretical studies of noise. Accordingly, the research method was used when noise level and traffic flow information were collected parallelly.

2. Using the equipment Flus ET-965, the average value of the generated noise was researched. Three typical street sections with different planning parameters and types of road pavement were selected as objects of research. The obtained values were analyzed in laboratory conditions. Based on these data, the graph dependencies were created.

3. Processing of record results was performed using Microsoft Excel software. Based on this, there was established that the noise level created by the traffic flow affected traffic intensity and the type of road pavement on which it moves. To assess the dependence between noise and traffic intensity, appropriate graphs were constructed. They reflect the need to take into account traffic parameters while designing new and improving existing streets and roads. This will allow counting the need or lack of the installation of protection against noise pollution.

4. The results show that the first typical section of the street has the lowest noise indicators, as the traffic intensity there is the lowest compared to the others, and there is a significant amount of greenery. Accordingly, it has been found that greenery helps reduce overall noise levels. In such conditions, the average value of the generated noise did not exceed sanitary norms. The second typical section of the street is characterized by the presence of trams and cobblestones road pavement, which increases the average value of noise pollution. This street has the highest noise levels. In the third typical street sections, the characteristic features are higher values of vehicle speed and traffic intense, in contrast to the previous two. Under the second and the third conditions, the average level of traffic noise is a bit higher than sanitary norms. Thus, during the design decisions, it is necessary to take into account the calculated values of traffic intensity and, if it is necessary, to create protective equipment - greenery and noise protection screens.

\section{References}

1. Jacyna, M., Wasiak, M., Lewczuk, K., \& Karoń, G. (2017). Noise and environmental pollution from transport: decisive problems in developing ecologically efficient transport systems. Journal of Vibroengineering, Volume 19, Issue 7, 5639-5655. doi: 10.21595/jve.2017.19371 (in English)

2. Eze, I., Foraster, M., Schaffner, E., Vienneau, D., Héritier, H., Pieren, R., \& et al. (2018). Transportation noise exposure, noise annoyance and respiratory health in adults: A repeated-measures study. Environment international, Volume 121, 741-750. doi: 10.1016/j.envint.2018.10.006 (in English)

3. Koch, C. (2017). Hearing beyond the limit: Measurement, perception and impact of infrasound and ultrasonic noise. 12th ICBEN Congress on Noise as a Public Health Problem, Zurich. (in English)

4. Khan, J., Ketzel, M., Kakosimos, K., Sørensen, M., \& Jensen, S. S. (2018). Road traffic air and noise pollution exposure assessment - A review of tools and techniques. Science of The Total Environment, Volume 634, 661-676. doi: 10.1016/j.scitotenv.2018.03.374 (in English)

5. Anees, M., Qasim, M., \& Bashir, A. (2017). Physiological and physical impact of noise pollution on environment. Earth Science Pakistan, Volume 1(1), 08-11. doi: 10.26480/esp.01.2017.08.10 (in English)

6. Morillas, J., Gozalo, G., González, D., Moraga, P., \& Vílchez-Gómez, R. (2018). Noise pollution and urban planning. Current Pollution Reports, Volume 4(3), 208-219. doi: 10.1007/s40726-018-0095-7 (in English)

7. Mavrin, V., Makarova, I., \& Prikhodko, A. (2018). Assessment of the influence of the noise level of road transport on the state of the environment. Transportation research procedia, Volume 36, 514-519. doi: 10.1016/j.trpro.2018.12.138 (in English)

8. Shevchenko Yu. (2016). Development of models for estimating and improving the efficiency of reducing traffic noise. Extended abstract of candidate's thesis. Kyiv (in Ukrainian).

9. Skorost avtomobylia i okruzhaiushchaia sreda. Chast 2. [Vehicle speed and environment. Part 2] Retrieved from: http://transspot.ru/2013/03/05/skorost-avtomobilya-i-okruzhayushhaya-sreda-chast-2/ (in Russian)

10. Vázquez, V., \& Paje, S. (2016). Study of the road surface properties that control the acoustic performance of a rubberised asphalt mixture. Applied Acoustics, Volume 102, 33-39. doi: 10.1016/j.apacoust.2015.09.008 (in English)

11. Yang, W., Cai, M., \& Luo, P. (2020). The calculation of road traffic noise spectrum based on the noise spectral characteristics of single vehicles. Applied Acoustics, Volume 160, 107-128. doi: 10.1016/j.apacoust.2019.107128 (in English) 
12. Aletta, F., Brinchi, S., Carrese, S., Gemma, A., Guattari, C., Mannini, L., \& Patella, S. M. (2020). Analysing urban traffic volumes and mapping noise emissions in Rome (Italy) in the context of containment measures for the COVID-19 disease. Noise Mapping, Volume 7(1), 114-122. doi: 10.1515/noise-2020-0010 (in English)

13. Okokon, E., Yli-Tuomi, T., Turunen, A., Taimisto, P., Pennanen, A., Vouitsis, I., \& et al. (2017). Particulates and noise exposure during bicycle, bus and car commuting: A study in three European cities. Environmental research, Volume 154, 181-189. doi: 10.1016/j.envres.2016.12.012 (in English)

14. Shum. Terminy ta vyznachennia [Noise. Terms and definitions]. (1995). DSTU ISO 2325-93 from 01th January 1995. Kyiv: Derzhstandart Ukraine (in Ukrainian) Russian)

15. ARM "Akustyka" [APM "Acoustics"] Retrieved from: http://www.noiseview.ru/acoustic/about/ (in

16. Mateichyk V., Weigang G. \& Yanovskyi V. (2016). Otsinka parametrychnoho zabrudnennia prydorozhnoho seredovyshcha miskymy transportnymy potokamy [Assessment of parametric environmental pollution of roadside by city traffic flow]. Naukovo-tekhnichnyi zbirnyk "Visnyk Natsionalnoho transportnoho universytetu" [The National Transport University Bulletin: A Scientific and Technical Journal], Volume 2, 141-150. (in Ukrainian)

17. Nastanova z rozrakhunku ta proektuvannia zakhystu vid shumu selbyshchnykh terytorii [Guidelines for the calculation and design of noise protection of residential areas]. (2014). DSTU ISO N B V.1.1-33: 2013 from 01th January 2014. Kyiv: Ministry of Regional Development (in Ukrainian)

18. ET-965 IN 1 Environment Meter. Retrieved from: https://www.szflus.com/products/et-965-in-1environment-meter/ (in English)

19. Hrytsun O. (2019). Justification of rational regimes of traffic light control taking into account traffic flow characteristics and pedestrian behavior. Extended abstract of candidate's thesis. Lviv: Lviv Polytechnic National University (in Ukrainian).

20. Avtomobilni dorohy. Chastyna I. Proektuvannia. Chastyna II. Budivnytstvoennia [Automobile roads. Part I Design. Part II Construction]. (2015). DBN ISO V. 2.3-4: 2015 from 21th September 2015. Kyiv: Ministry of Regional Development (in Ukrainian)

21. Zakhyst terytorii budynkiv $i$ sporud vid shumu [Protection of territories, buildings and structures from noise]. (2013). DBN ISO V.1.1-31:2013 from 01th June 2014. Kyiv: Ministry of Regional Development (in Ukrainian)

Received 12.02.2021; Accepted in revised form 09.04.2021.

\title{
ВПЛИВ ІНТЕНСИВНОСТІ ТРАНСПОРТНОГО ПОТОКУ НА ШУМОВЕ ЗАБРУДНЕННЯ ДОВКІЛЛЯ
}

\begin{abstract}
Анотація. Сучасне міське середовище із розвитком промисловості, зростанням кількості транспортних засобів на дорогах та збільшенням щільності забудови все більш негативно впливає на здоров'я $i$ благополуччя населення міста. Серед чинників впливу навколишнього середовища шумове забруднення, зокрема техногенний шум - небажані та шкідливі звуки, що створюються в результаті діяльності людини. Сьогодні шум є одним з найпоширеніших чинників забруднення. Найпоширенішим джерелом шумового забруднення $\epsilon$ транспорт, зокрема легкові та вантажні автомобілі, автобуси, залізничний транспорт, літаки тощо. Негативним наслідкомм транспортного шуму є те, щзо практично кожна людина значною мірою зазнає його впливу. Часто ие може супроводжуватися іншими шкідливими чинниками, наприклад, вібрацією. Згідно з науковими дослідженнями, шум може викликати роздратованість через постійний акустичний вплив. Унаслідок иього у людини виникають порушення сну, спостерігається зниження розумової працездатності та розви-
\end{abstract}


вається стрес. Транспортний шум створюють робота двигунів, тертя коліс об дорожнє покриття, гальма та аеродинамічні особливості транспортних засобів тощо. Загалом, рівень транспортного шуму залежить від таких основних показників, як інтенсивність, швидкість та склад транспортного потоку. Тому важливим завданням є дослідження автотранспортного шуму, його вимірювання, встановлення відповідних залежностей та подальше оцінювання результатів. Знаючи рівень шуму, створюваного транспортними засобами, можна вживати заходів щодо його зниження. Це, наприклад, перерозподіл руху транспортних потоків по вулично-дорожній мережі, обмеження швидкості руху, покращення якості дорожнього покриття, використання основних засобів зниження шумового забруднення, застосування шумозахисних пристроїв тощо. На основі иього можна знизити негативний вплив шумового забруднення на організм людини та довкілля загалом.

Ключові слова: транспортний потік, шумове забруднення, інтенсивність транспортного потоку, шумомір, дорожне покриття. 